\title{
Do Turkish IPOs Time the Market?
}

\author{
Süreyya Burcu Avci* \\ Sabancı University
}

\begin{abstract}
This paper tests whether entrepreneurs time the market in the Turkish IPO market to benefit from temporary market conditions. IPOs substantiated in Borsa Istanbul between 1990 and 2019 are analyzed to test the hypothesis. Findings support the market timing hypothesis: Hot issue markets are characterized by higher initial underpricing. During these periods, initial and aftermarket abnormal returns, real money left on the table, real proceeds from IPOs, and the ratio of new shares to total shares are higher. IPO volume is not significantly related to economic and financial market swings.
\end{abstract}

Keywords: IPOs, market timing, underpricing, cumulative abnormal returns, hot issue periods JEL Classification: G12, G14, G32

\section{Türkiye'deki İlk Halka Arzlarda Piyasa Zamanlaması}

\section{Özet}

Bu makale, Türkiye'de girişimcilerin pazardaki geçici fırsatlardan yararlanmak için ilk halka arz pazarına girişlerindeki stratejik zamanlamayı test etmektedir. Hipotezin test edilmesi için 1990 ve 2019 yılları arasında Borsa İstanbul'da gerçekleşen ilk halka arzlar analiz edilmiştir. Bulgular piyasa zamanlama hipotezini desteklemektedir: Sıcak ihraç pazarı yüksek oranda düşük fiyatlama ile karakterize edilmektedir. Sıcak ihraç pazarlarında ilk getiriler, satış sonrası anormal getiriler, masada kalan reel para, ihraçların reel tutarı ve yeni hisselerin toplam hisselere oranı daha yüksektir. İhraç hacmi ekonomik ya da finansal pazar dalgalanmaları ile anlamlı şekilde ilişkili değildir.

Anahtar Kelimeler: İlk halka arzlar, piyasa zamanlaması, düşük fiyatlama, birikmiş olă̆andışı getiriler, sıcak ihraç dönemleri

JEL Sinıflandırması: G12, G14, G32

\footnotetext{
* Süreyya Burcu Avcı. Visiting Researcher. Sabancı University School of Management.Orta Mahalle 34956 Tuzla Istanbul, Turkey. E-mail: avcis@ sabanciuniv.edu . Phone: +902164839000. ORCID ID: 0000-0001-8056-8509.

Boğaziçi Journal Review of Social, Economic and Administrative Studies, Vol. 34, no. 2 (2020), pp.114-134, doi: 10.21773/boun.34.2.2

Research Article | Received: 11.04.2020 - Accepted: 10.02.2021
} 
an market timing theory explain the variation in short-term profitability of investing in Turkish IPOs? Market timing theory predicts that when investors are excited about a particular industry, entrepreneurs will be happy to supply those IPOs at attractive (high) offering prices. ${ }^{1}$ Firms will be happy to issue stocks when the market overvalues their stocks. The theory predicts that IPOs from a particular industry will cluster in certain time periods (hot issue markets) when the valuation (company value or market-to-book ratio, MB) of IPO companies are higher than during other periods (Lucas and McDonald, 1990).

This paper tests whether market timing theory can explain the variability in Turkish IPOs for the last 30 years, the period from January 1990 to December 2019. There are 439 IPOs analyzed in the sample period. Initial and short-run cumulative abnormal returns of IPOs are computed as a measure of initial and short-run underpricing. The empirical tests find $9.7 \%$ percent initial underpricing for the entire sample period. The underpricing is less than $5 \%$ in the first five days of aftermarket trades, yet all numbers are significantly higher than zero. These results provide evidence of great short-term profits for IPO investors.

Hot and cold stock issue periods are determined in order to develop an idea about IPO volume in these periods. A hot issue period is the month with the highest number of issues (the highest quartile) in the sample while a cold issue period is the month with the lowest number of issues (the lowest two quartiles). The remaining months are labelled as neutral periods. A standard event study methodology is used to determine abnormal returns for the entire sample and issue sub-periods. Descriptive statistics of abnormal returns are reported to reveal the difference between hot and cold issue periods. Results show that cold and neutral issue markets have positive and statistically significant initial returns; however, initial underpricing is $7.18 \%$ higher in hot issue markets compared to cold issue periods. The similarity in initial returns for cold and neutral markets shows that there is not much difference between cold and neutral markets while hot market returns are significantly higher than cold and neutral market returns.

The variables used to measure IPO volume are the number of IPOs per month $(\mathrm{N})$ and a categorical variable (HC) that identifies issue periods. HC has values of one, two, and three for cold, neutral, and hot periods, respectively. To identify the dynamics of the IPO volume, univariate and multivariate regressions are run against financial and business cycle dummies, real gross proceeds from IPOs, real money left on the table after each IPO, the ratio of new shares to total shares and the ratio of public shares to total shares on the IPO date. Tobit regressions are used to deal with truncated data problems.

Multivariate regression analysis shows that real money left on the table and the new shares to total shares ratio capture the explanatory power of other variables, which are significant in univariate analysis as well. Findings indicate no evidence of a statistical relation between the categorical variable marking issue periods and financial or business cycles. Moreover, real

\footnotetext{
${ }^{1}$ Market timing theory does not explain the initial underpricing per se; it simply takes the initial underpricing as it is. Initial underpricing is observed in hot and cold market periods and it is assumed that it is caused by multiple factors. Market timing theorists focus on whether underpricing is more severe in hot issue markets than in cold issue markets. There is no consensus so far on what causes the underpricing and when it is more severe.
} 
proceeds from sale of IPOs and the ratio of public shares to total shares are not related to IPO volume. IPO volume is marginally related to real money left on the table and the ratio of new shares to total shares only. Findings indicate that IPO volume is related to particular stock characteristics rather than general financial and economic market conditions.

This study contributes to the IPO literature in a twofold manner. First, to the best of our knowledge, it is the first study that aims to explain the difference in initial abnormal returns in hot and cold markets of Turkish IPOs from a market timing point of view. Results show that there are hot markets where IPO volume reaches a peak. In these markets cumulative initial returns are higher than those in cold and neutral markets. Money left on the table after IPOs are realized are significantly higher in hot markets. A higher sum of money left on the table may call for more IPO volume for the next period. Second, the analysis covers the period from 1990 to 2019, the longest sample period thus far utilized in Turkish IPO studies. The results suggest that it is not necessarily the better economic or financial conditions of a given period, but actually the market valuation of stocks that paves the way for more IPOs. These results support market timing theory.

The remainder of the paper is organized as follows. The next section reviews the theoretical and empirical literature on market timing and puts forward the paper's hypotheses. The following sections introduce the data and methodology used in the analyses, and then present the study's analytical results. The last section concludes the study.

\section{Literature Review and Hypotheses}

The market timing theory put forward by Lucas and McDonald (1990) investigates why firms time their seasoned equity issuances. In their model, Lucas and McDonald assume that managers have an informational advantage over prospective investors regarding the fair value of their firms. The information is revealed to investors one period after the managers make their decision. Using their informational advantage, managers decide when to issue new equity: If the market overvalues the firm, managers will rush to issue. If the market undervalues the firm, managers will delay the issuance until the next overvaluation period. Schultz (2003) argues that firms rush to issue equities when stock prices are high (usually at market peaks) irrespective of the reason for the issue. Baker and Wurgler (2002) explains the market timing of IPOs as such: they issue equity when the market prices of companies are higher than book values or past market values and repurchase equity when the market prices are lower than book values or past market values.

It is well-known that the financial conditions of companies in the same sector and the financial conditions of some sectors have temporary similarities (Plotnicki and Szyszka, 2014). Moreover, there is evidence that IPO volumes and stock market valuations are correlated in the major stock exchanges worldwide (Loughran, et al., 1994). As a result, IPO volume and average initial returns are highly correlated (Lowry and Schwert, 2002). Clustering of IPOs may be explained based on these similarities. Many firms are overvalued simultaneously in the clustering periods. Once a pioneer company in an overvalued sector goes public, peers from the same sector or from other overvalued sectors follow the pioneer company. Companies want to take advantage of market conditions (Plotnicki and Szyszka, 2014). Using the information above, one can hypothesize that Turkish IPOs, if measured over time, will be seen to cluster in certain periods. 
H1: There is clustering of IPOs in certain periods.

There is evidence suggesting that clustering periods correspond to the expansionary phases of business cycles when adverse selection costs are lower and investment opportunities are abundant. Choe et al. (1993) finds that firms wait for expansionary periods to issue stocks. Pástor and Veronesi (2005) claims IPOs are timed based on market conditions. They find that IPOs cluster when return predictability is low, and aggregate profitability and prior uncertainty about post-IPO predictability is high. Loughran et al. (1994) tests whether companies in different countries cluster either because there are ample growth opportunities, or because they time the market to benefit from mis-valuations. Their findings support the latter case. Rajan and Servaes (1997) explains market timing by focusing on analyst comments. They find that higher underpricing leads to more analyst attention. When analysts are particularly optimistic about the growth potential of recent IPOs, more firms rush to go public. This information paves the way for testing whether Turkish IPOs are sensitive for business cycles' up-periods or stock market index increases.

H2: Clustering periods correspond to the expansionary periods of business cycles or increases in stock market index.

IPO initial underpricing is a largely theorized phenomenon and well-documented empirical finding in finance. IPOs are underpriced in all markets and almost all periods (Ibbotson, 1975; Ibbotson and Jaffe, 1975; Ritter, 1984; Ibbotson et al., 1988, 1994; Boulton et al., 2011; Ritter, 1991; Loughran and Ritter, 2004; Roosenboom, 2012). Mirroring the international evidence, underpricing is also observed in Turkish IPOs. Average abnormal initial return is above $10 \%$ in studies computing underpricing in the 1990s (Kiymaz, 1997a, 1997b, 2000; Durukan, 2002; Sevim and Akkoç, 2006). The average abnormal initial return is found to be lower than $10 \%$ in the 2000s (Küçükkocaoğlu, 2008; Altan and Hotamış, 2008; Ünlü and Ersoy, 2008; Bildik and Y1lmaz, 2008; Kirkkulak, 2009; Ercan and Çevikel, 2011; Elmas and Amanianganeh, 2013; Turan Kurtaran, 2013; Yıldırım and Dursun, 2016; Açıkgöz and Gökkaya, 2017). Studies conducted at the end of the 2000s or post-2010 find even lesser initial abnormal returns around 5\% (Tütüncü 2020a; 2020b; 2020c); however, initial abnormal returns are always statistically significant. Thus, IPO underpricing for the whole period is anticipated.

Initial returns of IPOs are explained as an extension of market timing theory. According to models developed on this topic, initial returns are determined to be conditional on contemporaneous offerings. Companies do not know the approximate level of initial underpricing when they file the initial forms of IPOs. Companies observe contemporaneous offerings during the book-building process. Proceeds' revisions of other IPOs provide information and companies thus develop expectations about their own initial returns. If there are large positive proceed updates in contemporaneous offerings, then prospective IPOs should expect higher initial returns (Benveniste and Spint, 1989; Lowry and Schwert, 2002; Benveniste et al., 2003). Moreover, historical records show that high initial returns are followed by spurts of IPOs (Lowry and Schwert, 2002). As a result, there is a relation between high initial returns and hot periods, but neither the direction of the relation nor its features are well-examined. Behavioral explanations understand 
underpricing based on investor sentiment or the propensity of investors to chase trends during windows of opportunity (Rajan and Servaes, 2002).

A strand of market timing theory coincides with information spillover theories. Subrahmanyam and Titman (1999) sets up a theoretical information spillover model of going public in economies where the development of capital markets is low. Firms have the advantage of going public if they can obtain costly information for a cheap price. Moreover, if the issue market is big, there is a positive externality for going public. Firms going public in clusters benefit from this externality. Alti (2005)'s information spillover model assumes that information about common valuation factors is revealed to the market after a pioneer IPO. The market finds it easier to value subsequent IPOs once they obtain the information from the pioneer IPO. Higher offer prices in pioneer IPOs reflect private information better and call for a larger volume of IPOs than lower offer prices do. All these theories and empirical findings indicate higher underpricing in hot issue markets. Thus, a higher level of underpricing in hot issue markets is expected.

Money left on the table is expected to be higher in hot issue markets (Plotnicki and Szyszka, 2014). Money left on the table refers to the amount that current shareholders lose because of the high offer price. The term is also related to issue size. Money left on the table is computed by multiplying the number of shares offered by the difference between the first trading day price and the offer price. It indirectly measures the volume of IPOs if the number of shares is assumed to be a proxy for the volume. If money left on the table is higher during hot issue periods, then one can claim that there is a positive relation between initial returns and the number of issues during hot periods. Therefore, it is anticipated that money left on the table is higher during hot issue periods.

H3: Underpricing and the money-left are higher in hot issue IPO markets.

\section{Methodology and Data}

\section{Methodology}

Initial Returns. The initial returns are computed as a percentage price change between the first trading day price and the offer price by equation (1). $\mathrm{P}_{\mathrm{i}, \mathrm{t}}$ represents the first trading day closing price and $\mathrm{P}_{\mathrm{i}, \mathrm{t}-1}$ represents the offer price of the IPO.

$$
\mathrm{R}_{\mathrm{i}, \mathrm{t}}=\left[\frac{P_{i, t}-P_{i, t-1}}{P_{i, t-1}}\right] * 100
$$

Market adjusted returns are computed to measure abnormal returns for each stock.

$$
\mathrm{AR}_{\mathrm{i}, \mathrm{t}}=\mathrm{R}_{\mathrm{i}, \mathrm{t}}-\mathrm{R}_{\mathrm{m}, \mathrm{t}}
$$


where AR is the daily abnormal return of stock $i$ at day $t . R_{i}$ is the daily return of stock $i$ and $R_{m}$ is the daily stock market portfolio return. The BIST100 index is assumed to be the average return on the market portfolio.

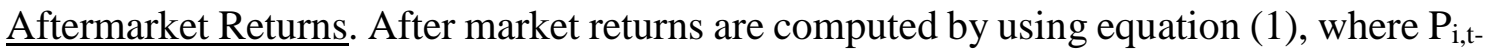
1 and $\mathrm{P}_{\mathrm{i}, \mathrm{t}}$ represent consecutive after-market returns. Event-time cumulative abnormal returns (CARs), are used to compute post-IPO price performance.

$$
\mathrm{CAR}_{\mathrm{i}, \mathrm{t}}=\sum_{i=1}^{n} A R_{i, t}
$$

CARs are computed for the first five days after the IPO. CARs are represented by two numbers of days. The first number is the first day of the cumulating, and the second number is the last day of cumulating. $C A R(0,0)$ represents the initial return, $C A R(0,5)$ represents the cumulative abnormal return for the first five days including the initial return, $C A R(1,3)$ represents the cumulative abnormal return for the first three days in the aftermarket. T-tests are used to test the statistical significance of CARs. Moreover, median values are also used to test the statistical significance because the dataset is not normally distributed. The Wilcoxon sign-rank test is employed to test the statistical significance of median values. CAR values are averaged each month in order to represent monthly initial abnormal returns. The average initial abnormal returns are labelled as CAR0.

In order to find the related variables to the number of IPOs, we use a Tobit regression model (Tobin, 1958). OLS regression is a biased estimator when the dependent variable is truncated. In our case, the number of IPOs cannot have a decimal or negative value and hot issue is a categorical variable. However, the nature of the relationship between $N$ or $H C$ and control variables might have required a linear relationship, which would have called for frictional or negative values of $N$. To avoid the biased estimators generated by OLS regressions, we run the following Tobit regression (Breen, 2011; Maddala, 2018):

$$
\begin{gathered}
Y_{i}=\alpha+\beta . X_{i}+\varepsilon_{i} \quad \text { if } Y_{i}>0 \\
Y_{i}=0 \text { otherwise. }
\end{gathered}
$$

\section{Data}

The data span of the analysis is the 30-year period from January 1990 to December 2019. The data for IPOs was collected from BIST Datastore ${ }^{2}$ and the Capital Markets Board of Turkey website ${ }^{3}$ and combined. This dataset provides a list of IPOs, dates, sales type, intermediary names, offer prices, the number of investors and other related information. The daily share prices, number of shares outstanding, and daily prices and volumes of the BIST100 index were obtained from

\footnotetext{
${ }^{2}$ https://datastore.borsaistanbul.com/

3 https://www.spk.gov.tr/Sayfa/AltSayfa/895
} 
EquityRT. After merging the datasets, a total of 448 IPOs were listed for the analysis period. Then, one IPO was excluded from the study because it went public for an acquisition. Its shares were replaced with the acquirer's shares just after the IPO date. Seven IPOs were eliminated because their daily share prices were not available. One IPO was eliminated due to the missing offer price. As a result, 439 IPOs were included in the analysis.

The variables used in this study are: The number of IPOs or IPO volume $(N)$ is the number of IPOs realized within a calendar month. The abnormal return $(A R)$ is the abnormal return calculated as the difference between the daily stock return and the daily stock market index return. The real aggregate gross proceeds in 2019 numbers (proceeds) are the monthly sum of real proceeds from each IPO. The lagged values of real aggregate gross proceeds in 2019 numbers (L.proceeds) are employed in the regression analysis. The real aggregate money left on the table in 2019 numbers (money_left) is computed as the number of shares offered multiplied by the difference between the first trading day closing price and the offer price. The money left on the table for each IPO is summed up monthly. The nominal values are transformed to real values by using the inflation calculator of the $\mathrm{TCMB}^{4}$. The lagged values of money left on the table (L.money_left) are also employed in the regression analysis. The ratio of primary shares to total shares (primary) is used in the regression analysis. The primary shares are an additional number of shares issued to increase the number of shares outstanding. They have a direct income effect for the company. The secondary shares refer to the resale of existing shares. They do not increase the number of shares outstanding. As a result, secondary shares do not have a direct income effect for the company (Kim and Weisbach, 2008). The total shares are the sum of primary and secondary shares. The IPO_ratio is the percentage of the company's public equity to total equity on the IPO date. The business cycle dummy $(B C)$ takes the value of 1 if the business cycle is in an expansionary period (growth in real GDP), and 0 otherwise. The stock exchange index dummy (SEI) takes the value of 1 if market index (BIST100) increases in a quarter, and 0 otherwise. $B C$ and SEI series are available for the 1990-2015 period, and are obtained from Binici et al. (2018). The hot-and-cold-period categorical variable $(H C)$ takes the value of three if the period is hot, two if the period is neutral, and one if the period is cold. CARs are cumulative abnormal returns computed using daily stock and BIST100 returns. CARO represents average cumulative initial abnormal returns. The descriptive statistics of variables are displayed in Table 1.

Table 1 shows the summary of $N, H C$, money_left, L.money_left, proceeds, L.proceeds, primary, and IPO_ratio, BC, SEI, and CARO. The average $N$ is 1.22 in 360 months, with a minimum value of 0 and maximum value of 8 . The categorical variable $H C$ averages at 2.41. Primary, and $I P O \_$ratio are dummy variables with averages of $20 \%$ and $27 \%$ for the cross-section. $B C$ and SEI are dummy variables defined between 1990 and 2015, as a result their number of observations is limited to 312 months. The cross-sectional average of CARO is $10 \%$. The mean value of money_left and proceeds are 90 million TL and 250 million TL, respectively.

\footnotetext{
${ }^{4}$ Inflation calculator: http://www3.tcmb.gov.tr/enflasyoncalc/enflasyon_anayeni.php
} 


\section{Table 1 Descriptive Statistics}

This table provides a summary of the variables used in the analysis. $N$ is IPO volume (number of IPOs per month), $H C$ is a dummy variable taking the value of 1 if a particular year is a hot IPO market, 0 otherwise. Money_left is real aggregate moneyleft on the table with 2019 numbers. Money_left is computed by multiplying the number of shares offered by the difference between the first trading day close price and the offer price. Proceeds are real aggregate gross proceeds with 2019 numbers. Proceeds are computed by multiplying the number of issues sold by sales price at the offer market. Money_left and proceeds are in Billion Turkish Liras. $B C$ is a dummy variable taking the value of 1 if a particular year is in a business-up cycle, 0 otherwise. SEI is a dummy variable taking the value of 1 if the BIST100 index increases in a particular year, 0 otherwise. Primary is the ratio of primary shares to total shares. The primary shares are the additional number of shares issued to increase the number of shares outstanding. IPO_Ratio is the percentage of the company's public equity to total equity on the IPO date. $C A R O$ is the monthly average of $C A R(0,0)$ values.

\begin{tabular}{|c|c|c|c|c|c|}
\hline Variables & Observations & Mean & $\begin{array}{c}\text { Standard } \\
\text { Deviation }\end{array}$ & Min & Max \\
\hline $\bar{N}$ & 360 & 1.22 & 1.53 & 0.00 & 8.00 \\
\hline$H C$ & 439 & 2.41 & 0.78 & 1.00 & 3.00 \\
\hline Money_Left & 439 & 0.09 & 0.50 & -0.78 & 7.58 \\
\hline Proceeds & 436 & 0.25 & 0.90 & 0.00 & 13.90 \\
\hline$B C$ & 312 & 0.82 & 0.39 & 0.00 & 1.00 \\
\hline SEI & 312 & 0.69 & 0.46 & 0.00 & 1.00 \\
\hline Primary & 403 & 0.20 & 0.35 & 0.00 & 1.00 \\
\hline IPO_Ratio & 438 & 0.27 & 0.21 & 0.00 & 1.00 \\
\hline CARO & 439 & 0.10 & 0.27 & -0.30 & 3.23 \\
\hline
\end{tabular}

\section{Table 2 Pairwise Correlations}

This table provides pairwise correlations between variables. $N$ is IPO volume (number of IPOs per month), $H C$ is a dummy variable taking the value of 1 if a particular year is a hot IPO market, 0 otherwise. Money_left is real aggregate money-left on the table with 2019 numbers. Money_left is computed by multiplying the number of shares offered by the difference between the first trading day close price and the offer price. Proceeds are real aggregate gross proceeds with 2019 numbers. Proceeds are computed by multiplying the number of issues sold by the sales price at the offer market. Money_left and proceeds are in Billion Turkish Liras. $B C$ is a dummy variable taking the value of 1 if a particular year is in a business-up cycle, 0 otherwise. SEI is a dummy variable taking the value of 1 if the BIST100 index increases in a particular year, 0 otherwise. Primary is the ratio of primary shares to total shares. The primary shares are the additional number of shares issued to increase the number of shares outstanding. $I P O \_$Ratio is the percentage of the company's public equity to total equity on the IPO date. $C A R O$ is the monthly average of $C A R(0,0)$ values. 


\begin{tabular}{|c|c|c|c|c|c|c|c|c|c|}
\hline Variables & $N$ & $H C$ & Money_Left & Proceeds & $B C$ & SEI & Primary & IPO_Ratio & CARO \\
\hline$N$ & 1 & & & & & & & & \\
\hline$H C$ & $0.91 *$ & 1 & & & & & & & \\
\hline Money_Left & $0.16^{*}$ & 0,13 & 1 & & & & & & \\
\hline Proceeds & 0.10 & 0.10 & $0.53 *$ & 1 & & & & & \\
\hline$B C$ & $0.14 *$ & $0.13^{*}$ & 0.09 & 0.10 & 1 & & & & \\
\hline SEI & -0.01 & -0.02 & 0.02 & -0.06 & $0.12 *$ & 1 & & & \\
\hline Primary & 0.01 & -0.13 & 0.02 & 0.02 & 0.05 & -0.05 & 1 & & \\
\hline IPO_Ratio & -0.12 & -0.24 & -0.11 & 0.07 & -0.09 & -0.04 & 0.03 & 1 & \\
\hline CARO & 0.03 & 0.01 & $0.19 *$ & -0.05 & 0.04 & 0.10 & -0.01 & -0.07 & 1 \\
\hline
\end{tabular}

Table 2 displays the pairwise correlation coefficients between variables. There is a $91 \%$ positive correlation between $N$ and $H C$. $N$ is positively correlated with money_left (16\%) and $B C$ (14\%). $H C$ is correlated with $B C(13 \%)$. Moreover, a strong positive correlation between moneyleft (and L.money_left) and proceeds is observed. BC and SEI are positively correlated (12\%); CARO and money_left are highly correlated (19\%). Money_left and proceeds, and BC and SEI will not be placed as dependent variables in the same regression analysis due to possible multicollinearity issues.

\section{Empirical Findings}

\section{Initial Returns and Aftermarket Returns}

Table 3 is formed to frame the annual outlook of Turkish IPOs between 1990 and 2019. The number of IPOs $(N)$, average initial abnormal returns $(A R)$, aggregate real gross proceeds (with December 2019 numbers) (proceeds), and aggregate real money left on the table (with December 2019 numbers) (money_left), the ratio of new shares to total shares (primary), and the ratio of public shares to total shares (IPO_ratio) per year are displayed in Table 3.

Periodic trends in the number of annual issues can be observed in Table 3. The number of IPOs is higher for 1990-2000, and the 2010-2014 period. The average number of observations between 1990 and 2000 is 23 per year. The numbers of IPOs drop to single digit numbers for the 2001-2009 period, with an average issue of six per year. The number of IPOs average 21 a year for the 2010-2014 period. The 2015-2019 period average is five issues a year.

Average initial abnormal returns fluctuate between $26.35 \%$ (1996) and -2.00\% (2002) with a $10.10 \%$ average over 30 years. Average abnormal returns are higher prior to the 2000 s; however, the average falls to single digit numbers in later years. Proceeds, money_left, primary, and $I P O \_$ratio follow a path with maximum values during the 2000 s. 
Table 3 Times Series Summary Statistics of IPOs

This table provides an annual summary of $N, A R$, proceeds, and money_left, IPO_ratio, and primary variables. $N$ is IPO volume (number of IPOs), $A R$ is market adjusted abnormal returns, proceeds are real aggregate gross proceeds with 2019 numbers. Proceeds are computed by multiplying the number of issues sold by the sales price at the offer market. Money_left is real aggregate money-left on the table with 2019 numbers. Money_left is computed by multiplying the number of shares offered by the difference between the first trading day close price and the offer price. IPO_Ratio is the percentage of the company's public equity to total equity on the IPO date. Primary is the ratio of primary shares to total shares. The primary shares are the additional number of shares issued to increase the number of shares outstanding.

\begin{tabular}{|c|c|c|c|c|c|c|}
\hline Year & $N$ & CARO & $\begin{array}{l}\text { Proceeds } \\
\text { (Millions) }\end{array}$ & $\begin{array}{c}\text { Money- } \\
\text { Left } \\
\text { (Millions) }\end{array}$ & IPO_Ratio & Primary \\
\hline 1990 & 32 & $24.97 \%$ & 307.00 & 256.00 & $16.44 \%$ & $35.60 \%$ \\
\hline 1991 & 22 & $3.35 \%$ & 167.00 & -4.20 & $30.90 \%$ & $21.29 \%$ \\
\hline 1992 & 11 & $5.23 \%$ & 65.10 & 18.60 & $18.73 \%$ & $0.00 \%$ \\
\hline 1993 & 16 & $11.41 \%$ & 83.50 & 45.50 & $18.19 \%$ & $9.31 \%$ \\
\hline 1994 & 25 & $5.91 \%$ & 113.00 & 18.20 & $23.16 \%$ & $22.54 \%$ \\
\hline 1995 & 29 & $17.53 \%$ & 78.00 & 34.40 & $33.45 \%$ & $17.88 \%$ \\
\hline 1996 & 25 & $26.35 \%$ & 54.80 & 41.20 & $28.54 \%$ & $19.46 \%$ \\
\hline 1997 & 31 & $12.77 \%$ & 126.00 & 97.50 & $23.27 \%$ & $22.86 \%$ \\
\hline 1998 & 20 & $10.45 \%$ & 165.00 & 55.10 & $26.30 \%$ & $16.42 \%$ \\
\hline 1999 & 9 & $13.16 \%$ & 76.60 & 63.50 & $40.89 \%$ & $11.11 \%$ \\
\hline 2000 & 36 & $9.17 \%$ & 613.00 & 351.00 & $19.94 \%$ & $14.44 \%$ \\
\hline 2001 & 1 & $0.87 \%$ & 2.59 & 0.26 & $49.00 \%$ & $0.00 \%$ \\
\hline 2002 & 4 & $-2.00 \%$ & 116.00 & -54.10 & $25.00 \%$ & $0.00 \%$ \\
\hline 2003 & 2 & $7.20 \%$ & 43.20 & 6.80 & $35.00 \%$ & $60.00 \%$ \\
\hline 2004 & 12 & $2.38 \%$ & 241.00 & 20.40 & $33.25 \%$ & $25.25 \%$ \\
\hline 2005 & 7 & $5.10 \%$ & 344.00 & 48.10 & $58.00 \%$ & $48.43 \%$ \\
\hline 2006 & 15 & $7.32 \%$ & 286.00 & 168.00 & $49.00 \%$ & $11.00 \%$ \\
\hline 2007 & 9 & $9.72 \%$ & $1,520.00$ & 728.00 & $47.44 \%$ & $34.22 \%$ \\
\hline 2008 & 2 & $10.48 \%$ & $3,370.00$ & 101.00 & $57.00 \%$ & $50.00 \%$ \\
\hline 2009 & 1 & $2.59 \%$ & 26.50 & 1.97 & $25.00 \%$ & $0.00 \%$ \\
\hline 2010 & 20 & $5.10 \%$ & 374.00 & 63.60 & $27.95 \%$ & $12.85 \%$ \\
\hline 2011 & 27 & $5.97 \%$ & 116.00 & 26.80 & $27.59 \%$ & $18.83 \%$ \\
\hline 2012 & 26 & $4.07 \%$ & 50.60 & 0.67 & $14.50 \%$ & $18.71 \%$ \\
\hline 2013 & 18 & $6.47 \%$ & 153.00 & 11.00 & $11.72 \%$ & $8.07 \%$ \\
\hline 2014 & 13 & $2.90 \%$ & 97.80 & 3.06 & $18.85 \%$ & $33.67 \%$ \\
\hline 2015 & 6 & $4.34 \%$ & 33.60 & 3.93 & $32.83 \%$ & $16.60 \%$ \\
\hline 2016 & 2 & $-0.83 \%$ & 272.00 & -0.57 & $25.50 \%$ & $6.50 \%$ \\
\hline 2017 & 3 & $4.04 \%$ & 595.00 & 37.20 & $40.67 \%$ & $16.67 \%$ \\
\hline 2018 & 9 & $5.12 \%$ & 781.00 & 19.90 & $32.44 \%$ & $29.14 \%$ \\
\hline 2019 & 6 & $6.84 \%$ & 45.50 & 10.50 & $35.17 \%$ & $33.33 \%$ \\
\hline Total & 439 & $10.10 \%$ & 246.00 & 93.50 & $30.86 \%$ & $20.47 \%$ \\
\hline
\end{tabular}


Figure 1 IPO Volume, Real Proceeds and Real Money Left on the Table

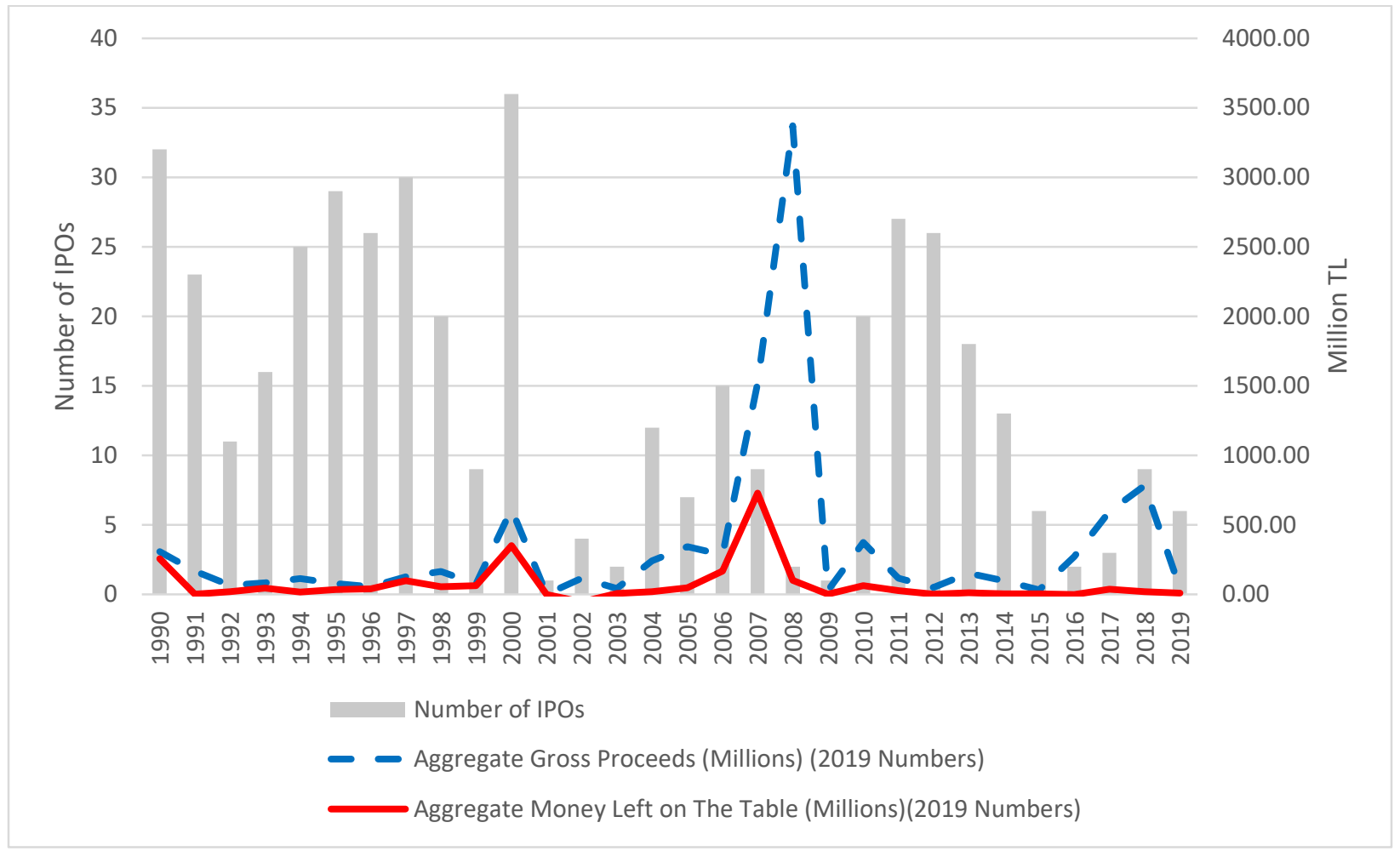

Figure 1 is a graphical illustration of $N$, proceeds, and money_left. This figure helps us see the direction of the relationship among variables. The relationship between $N$ and proceeds seems negative while the relationship between $N$ and money-left seems positive but weaker on an annual basis.

Table 4 reports the CARs of the equally weighted portfolios of 439 IPOs and their summary statistics for the entire sample. The initial return, $C A R(0,0)$ is $9.70 \%$ for the entire period. The short-term means of cumulative abnormal returns, from $C A R(0,1)$ to $C A R(0,5)$, range monotonically between $12.04 \%$ and $14.23 \%$. Short-term cumulative aftermarket cumulative abnormal returns, $C A R(1,1)$ to $C A R(1,5)$, range between $2.35 \%$ and $4.53 \%$. Aftermarket returns are remarkably lower than initial returns; however, all mean values in Table 4 are significantly different from 0 . The significance level is $1 \%$ for each case.

The median initial cumulative abnormal return is $4.62 \%$ and significant at a $1 \%$ level according to the Wilcoxon sign rank test. Short-term median values range between $3.80 \%$ and $4.45 \%$, significant at a $1 \%$ level. However, aftermarket median values are all negative and range between $-0.11 \%$ and $-.87 \%$. The aftermarket median values of cumulative abnormal returns are statistically insignificant from 0 . Significantly positive median initial returns and insignificant median aftermarket returns indicate that initial investors earn large profits while aftermarket profits are not different from zero. 
Table 4 Cumulative Abnormal Returns (CARs) and Summary Statistics for the Entire Period

This table provides a summary of cumulative abnormal returns (CARs). The sample is populated with the difference between the daily returns of initial and aftermarket returns of IPOs and the BIST100 index. $C A R(0,0)$ is the initial return. $C A R(0,1)-C A R(0,5)$ are one- to five-day market adjusted cumulative abnormal returns. $C A R(1,1)-C A R(1,5)$ are one- to five-day market adjusted aftermarket cumulative abnormal returns. $* * * \mathrm{p}<0.01, * * \mathrm{p}<0.05, * \mathrm{p}<0.1$

\begin{tabular}{lccccccc}
\hline Variable & Observations & Mean & Median & Min. & Max. & t-Value & Z-Value \\
\hline$C A R(0,0)$ & 439 & $9.70 \% * * *$ & $4.62 \% * * *$ & $-29.70 \%$ & $323.14 \%$ & 7.62 & 10.44 \\
$C A R(0,1)$ & 439 & $12.04 \% * * *$ & $4.34 \% * * *$ & $-34.00 \%$ & $317.79 \%$ & 8.18 & 9.27 \\
$C A R(0,2)$ & 439 & $12.89 \% * * *$ & $3.80 \% * * *$ & $-44.73 \%$ & $311.32 \%$ & 8.38 & 8.35 \\
$C A R(0,3)$ & 439 & $13.73 \% * * *$ & $4.45 \% * * *$ & $-59.18 \%$ & $310.84 \%$ & 8.44 & 8.12 \\
$C A R(0,4)$ & 439 & $13.58 \% * * *$ & $4.43 \% * * *$ & $-57.05 \%$ & $313.13 \%$ & 8.1 & 7.59 \\
$C A R(0,5)$ & 439 & $14.23 \% * * *$ & $4.33 \% * * *$ & $-64.77 \%$ & $316.21 \%$ & 7.87 & 7.4 \\
$C A R(1,1)$ & 439 & $2.35 \% * * *$ & $-0.13 \% *$ & $-18.22 \%$ & $230.65 \%$ & 3.59 & 1.79 \\
$C A R(1,2)$ & 439 & $3.20 \% * * *$ & $-0.69 \%$ & $-25.87 \%$ & $228.07 \%$ & 4.05 & 1.1 \\
$C A R(1,3)$ & 439 & $4.03 \% * * *$ & $-0.58 \%$ & $-40.32 \%$ & $234.93 \%$ & 4.36 & 1.59 \\
$C A R(1,4)$ & 439 & $3.89 \% * * *$ & $-0.87 \%$ & $-38.69 \%$ & $229.23 \%$ & 3.86 & 1.37 \\
$C A R(1,5)$ & 439 & $4.53 \% * * *$ & $-0.11 \%$ & $-46.38 \%$ & $242.41 \%$ & 3.75 & 1.44 \\
\hline
\end{tabular}

The large difference between the mean and median values in the aftermarket period indicate a growing average return for the IPO companies. The difference indicates that the number of above-mean abnormal returns is few; however, the magnitude of abnormal returns is large. (A small number of high abnormal-return IPOs lead the statistics. The abnormal returns of these companies grow each day.) The extreme values of maximum and more humble values of minimum cumulative abnormal returns support this argument. For example, the maximum value for $\operatorname{CAR}(0,0)$ is $323 \%$ while the minimum value for the same variable is only $-29,70 \%$.

\section{Clustering of IPOs, Hot and Cold IPO Markets, Initial and Short-Run Returns}

Market timing theory distinguishes between hot and cold issue periods. A distinguishable pattern in the number of IPOs between hot and cold issue periods should be expected if the market timing theory holds. A way to distinguish hot and cold issue periods is to determine the number of issuances in each month and group these numbers into five categories based on quartiles (Helwege and Liang, 2004). Following this method, the number of IPOs in each of the 360 months in the sample period is determined. The highest quartile months are labelled as the hot period. The lowest two quartiles are labelled as the cold period, because there are only a few IPOs in the lowest quartile. The third and fourth quartiles are designated neutral periods. Based on this classification, the hot, neutral, and cold periods in the dataset contain 206, 172, and 61 observations, respectively. These numbers show that there is clustering in some periods and the number of issues is higher in hot periods.

Table 5 reports the average $C A R O$, proceeds, money-left, primary, and IPO_ratio values for hot, neutral, and cold periods. There is a remarkable difference between hot and cold period CARO values, proceeds, and money-left. The difference in CARO values between hot and cold periods is $7.18 \%$. N, CARO, proceeds, money_left, and primary are higher in hot periods. Neutral 
period values have closer proximity to cold period values than hot period values. The IPO_ratio is higher during cold periods.

\section{Table 5 Summary of IPOs for Hot, Neutral, and Cold Periods}

This table provides a summary of $N, C A R O$, proceeds, money_left, IPO_Ratio, and Primary in hot, neutral, and cold issue markets. $N$ is IPO volume (number of IPOs). Average CARO is the average value of $\operatorname{CAR}(0,0)$ for hot, neutral, and cold issue markets. Proceeds are real aggregate gross proceeds with 2019 numbers. Proceeds are computed by multiplying the number of issues sold by sales price at the offer market. Money_left is the real aggregate money-left on the table with 2019 numbers. Money_left is computed by multiplying the number of shares offered by the difference between the first trading day close price and the offer price. IPO_ratio is the percentage of the company's public equity to total equity on the IPO date. Primary is the ratio of primary shares to total shares. The primary shares are the additional number of shares issued to increase the number of shares outstanding. Hot represents hot issue markets, neutral represents neutral issue markets, and cold represents cold issue markets.

\begin{tabular}{|c|c|c|c|c|c|c|}
\hline Variable & $N$ & CARO & $\begin{array}{c}\text { Proceeds } \\
\text { (Million TL) }\end{array}$ & $\begin{array}{l}\text { Money-Left } \\
\text { (Million TL) }\end{array}$ & IPO_Ratio & Primary \\
\hline $\mathrm{Hot}$ & 206 & $14.43 \%$ & 274.00 & 122.00 & $25.55 \%$ & $21.86 \%$ \\
\hline Neutral & 172 & $6.25 \%$ & 241.00 & 58.60 & $26.68 \%$ & $18.58 \%$ \\
\hline Cold & 61 & $6.49 \%$ & 165.00 & 44.20 & $29.37 \%$ & $16.76 \%$ \\
\hline
\end{tabular}

Table 6 represents the summary statistics of CARs for hot (Panel A), neutral (Panel B), and cold issue periods (Panel C). The average abnormal initial returns for hot, neutral, and cold periods are $13.60 \%, 6.18 \%$, and $6.42 \%$, respectively. There is a $7.18 \%$ difference between hot and cold periods. The median initial abnormal returns are significant in all sub-periods at a $1 \%$ level. The hot and cold period median difference is $0.44 \%$ only. The small median difference versus the large mean difference between hot and cold issue markets imply that extreme positive values make a huge contribution to inflated mean values during hot periods.

Cold and neutral markets are similar to each other from a holistic point of view: Initial abnormal returns are about $6 \%$ in both sub-periods. The difference in return patterns between hot markets and other markets is remarkable. The Welch t-statistics suggest that hot issue period abnormal returns are significantly different from the abnormal returns of neutral and cold issue periods. Thus, it is reasonable to claim that hot periods are different from other periods with regards to return patterns: Initial returns and short-run CARs are higher for hot periods. On the other hand, initial returns and short-run CARs are positive during neutral and cold periods but they are lower during hot issue periods. 
Table 6 Cumulative Abnormal Returns (CARs) and Summary Statistics for Hot, Neutral, and Cold Periods

This table provides the summary of cumulative abnormal returns (CARs) in hot, neutral, and cold issue markets. $\operatorname{CAR}(0,0)$ is the initial return. $\operatorname{CAR}(0,1)-C A R(0,5)$ are one- to five-day market adjusted cumulative abnormal returns. $\operatorname{CAR}(1,1)-C A R(1,5)$ are one- to five-day market adjusted aftermarket cumulative abnormal returns. $* * * \mathrm{p}<0.01, * * \mathrm{p}<0.05, * \mathrm{p}<0.1$.

\begin{tabular}{|c|c|c|c|c|c|c|c|}
\hline \multicolumn{8}{|c|}{ Panel A: Hot Period } \\
\hline Variable & Obs. & Mean & Median & Min. & Max. & t-Stat & Z-Stat. \\
\hline $\operatorname{CAR}(0,0)$ & 206 & $13.60 \% * * *$ & $4.80 \% * * *$ & $-29.70 \%$ & $323.14 \%$ & 5.28 & 6.87 \\
\hline $\operatorname{CAR}(0,1)$ & 206 & $15.58 \% * * *$ & $4.28 \% * * *$ & $-34.00 \%$ & $317.79 \%$ & 5.84 & 6.18 \\
\hline $\operatorname{CAR}(0,2)$ & 206 & $15.82 \% * * *$ & $2.86 \% * * *$ & $-40.80 \%$ & $311.32 \%$ & 5.84 & 5.48 \\
\hline $\operatorname{CAR}(0,3)$ & 206 & $16.78 \% * * *$ & $5.09 \% * * *$ & $-47.18 \%$ & $310.84 \%$ & 6.00 & 5.68 \\
\hline $\operatorname{CAR}(0,4)$ & 206 & $16.36 \% * * *$ & $4.52 \% * * *$ & $-57.05 \%$ & $313.13 \%$ & 5.68 & 5.08 \\
\hline $\operatorname{CAR}(0,5)$ & 206 & $16.43 \% * * *$ & $4.67 \% * * *$ & $-64.77 \%$ & $316.21 \%$ & 5.57 & 4.98 \\
\hline $\operatorname{CAR}(1,1)$ & 206 & $1.97 \% * * *$ & $-0.13 \%$ & $-13.77 \%$ & $30.98 \%$ & 3.54 & 1.17 \\
\hline $\operatorname{CAR}(1,2)$ & 206 & $2.22 \% * * *$ & $-0.78 \%$ & $-19.85 \%$ & $53.73 \%$ & 2.60 & 0.11 \\
\hline $\operatorname{CAR}(1,3)$ & 206 & $3.18 \% * * *$ & $-0.30 \%$ & $-30.40 \%$ & $67.12 \%$ & 2.92 & 0.89 \\
\hline $\operatorname{CAR}(1,4)$ & 206 & $2.76 \% * *$ & $-0.98 \%$ & $-38.69 \%$ & $89.54 \%$ & 2.13 & 0.32 \\
\hline $\operatorname{CAR}(1,5)$ & 206 & $2.83 \% * *$ & $0.04 \%$ & $-46.38 \%$ & $106.81 \%$ & 1.97 & 0.56 \\
\hline \multicolumn{8}{|c|}{ Panel B: Neutral Period } \\
\hline $\operatorname{CAR}(0,0)$ & 172 & $6.18 \% * * *$ & $4.61 \% * * *$ & $-20.38 \%$ & $54.40 \%$ & 7.54 & 6.64 \\
\hline $\operatorname{CAR}(0,1)$ & 172 & $9.25 \% * * *$ & $4.27 \% * * *$ & $-33.86 \%$ & $241.01 \%$ & 5.04 & 5.65 \\
\hline $\operatorname{CAR}(0,2)$ & 172 & $10.82 \% * * *$ & $4.60 \% * * *$ & $-44.73 \%$ & $238.43 \%$ & 5.29 & 5.24 \\
\hline $\operatorname{CAR}(0,3)$ & 172 & $11.80 \% * * *$ & $4.52 \% * * *$ & $-59.18 \%$ & $245.29 \%$ & 5.25 & 5.04 \\
\hline $\operatorname{CAR}(0,4)$ & 172 & $12.03 \% * * *$ & $4.67 \% * * *$ & $-55.02 \%$ & $239.59 \%$ & 5.17 & 4.80 \\
\hline $\operatorname{CAR}(0,5)$ & 172 & $13.76 \% * * *$ & $4.15 \% * * *$ & $-59.79 \%$ & $249.93 \%$ & 4.90 & 4.66 \\
\hline $\operatorname{CAR}(1,1)$ & 172 & $3.07 \% * *$ & $-0.20 \%$ & $-18.22 \%$ & $230.65 \%$ & 2.06 & 1.20 \\
\hline $\operatorname{CAR}(1,2)$ & 172 & $4.64 \% * * *$ & $-0.62 \%$ & $-25.87 \%$ & $228.07 \%$ & 2.80 & 1.41 \\
\hline $\operatorname{CAR}(1,3)$ & 172 & $5.62 \% * * *$ & $-0.52 \%$ & $-40.32 \%$ & $234.93 \%$ & 3.04 & 1.64 \\
\hline $\operatorname{CAR}(1,4)$ & 172 & $5.85 \% * * *$ & $-0.34 \%$ & $-36.16 \%$ & $229.23 \%$ & 3.04 & 1.57 \\
\hline $\operatorname{CAR}(1,5)$ & 172 & $7.58 \% * * *$ & $-0.32 \%$ & $-42.11 \%$ & $242.41 \%$ & 3.08 & 1.47 \\
\hline \multicolumn{8}{|c|}{ Panel C: Cold Period } \\
\hline $\operatorname{CAR}(0,0)$ & 61 & $6.42 \% * * *$ & $4.36 \% * * *$ & $-14.31 \%$ & $29.56 \%$ & 5.15 & 4.31 \\
\hline $\operatorname{CAR}(0,1)$ & 61 & $7.99 \% * * *$ & $5.34 \% * * *$ & $-25.61 \%$ & $39.77 \%$ & 4.40 & 3.94 \\
\hline $\operatorname{CAR}(0,2)$ & 61 & $8.83 \% * * *$ & $4.03 \% * * *$ & $-27.09 \%$ & $60.39 \%$ & 3.90 & 3.69 \\
\hline $\operatorname{CAR}(0,3)$ & 61 & $8.87 \% * * *$ & $3.35 \% * * *$ & $-38.06 \%$ & $81.15 \%$ & 3.26 & 3.19 \\
\hline $\operatorname{CAR}(0,4)$ & 61 & $8.60 \% * * *$ & $4.22 \% * * *$ & $-45.00 \%$ & $81.28 \%$ & 3.10 & 3.16 \\
\hline $\operatorname{CAR}(0,5)$ & 61 & $8.11 \% * * *$ & $4.59 \% * * *$ & $-38.46 \%$ & $67.31 \%$ & 3.03 & 3.14 \\
\hline $\operatorname{CAR}(1,1)$ & 61 & $1.57 \% *$ & $0.06 \%$ & $-11.30 \%$ & $20.42 \%$ & 1.71 & 0.62 \\
\hline $\operatorname{CAR}(1,2)$ & 61 & $2.42 \% *$ & $0.00 \%$ & $-17.98 \%$ & $40.58 \%$ & 1.67 & 0.35 \\
\hline $\operatorname{CAR}(1,3)$ & 61 & $2.45 \%$ & $-1.44 \%$ & $-23.75 \%$ & $54.72 \%$ & 1.30 & -0.28 \\
\hline $\operatorname{CAR}(1,4)$ & 61 & $2.18 \%$ & $-0.88 \%$ & $-31.32 \%$ & $54.86 \%$ & 1.10 & 0.28 \\
\hline $\operatorname{CAR}(1,5)$ & 61 & $1.69 \%$ & $-1.58 \%$ & $-32.37 \%$ & $41.35 \%$ & 0.90 & 0.08 \\
\hline
\end{tabular}




\section{Hot and Cold IPO Markets, Business Cycles, Bull and Bear Stock Markets, and the Money Left on the Table}

To test the relation between hot and cold market returns, business cycles, stock market indexes, and the money left on the table, the following univariate regression analysis was conducted. The dependent variable of the analysis is either the number of issues per month $(N)$ or the hot and cold period dummy variable $(H C)$. Independent variables are the business cycle dummy $(B C)$, or the stock exchange index dummy (SEI), the money left on the table (money_left) or the lag of money left on the table (L.money_left.)

$$
\mathrm{Y}_{\mathrm{t}}=\alpha+\beta . \mathrm{X}_{\mathrm{t}}+\varepsilon
$$

where trepresents months, Yt is either $N$ or $H C$, and $\mathrm{X}_{\mathrm{t}}$ is either $B C, S E I$, money_left, L.money_left, primary, or IPO_ratio. Because the nature of $N$ and $H C$ is categorical and bounded, the Tobit regression is preferred.

Univariate regression results are displayed in Table 7. The dependent variable is $N$ on the right-hand side, and $H C$ on the left-hand side of the table. Both $N$ and $H C$ have a positive and significant relation with $B C$, money_left, and L. money_left. Primary has a negative coefficient and is marginally significant when the dependent variable is $H C$. However, the relation between dependent variables and the financial cycle (SEI), and IPO_ratio is insignificant. These findings provide evidence for a positive relationship between hot issue markets and the business cycle, but not the financial cycle.

Next, to find the possible explanatory factors of IPO volume, the following multivariate regression is conducted.

$$
Y_{\mathrm{t}}=\alpha+\beta_{1} . B C_{\mathrm{t}}+\beta_{2} . Z_{t}+\varepsilon_{\mathrm{t}}
$$

where t represents months, Y represents $N$ or $H C$, and Z represents either money_left, L.money_left, or primary. All variables are monthly average values. SEI and IPO_ratio are ignored because they were not significant in the univariate regressions.

Regression results are presented in Table 8. Columns (1) and (2) show that money_left is significant at a $5 \%$ level when $N$ is the dependent variable, and at a $10 \%$ level when $H C$ is the dependent variable. Columns (3) and (4) have primary as an additional variable to $B C$ and money_left. Primary has a negative sign, and it is significant at $10 \%$ when the dependent variable is HC. The last four columns replace money_left with L.money_left. The coefficients of L.money_left are positive and significant for columns (5) and (6), indicating a positive relation between current IPO volume and the previous year's real money-left on the table. However, once we add primary to the model, all variables lose significance as reported in the last two columns. $B C$ is not significant in any multivariate regressions. Results show that money_left seizes the explanatory power from $B C$. Primary seizes explanatory power if the dependent variable is $H C$. The relationship between $N$ or $H C$ and money_left has a marginally significant positive coefficient 
after controlling for the business cycle; the relation between primary and $H C$ has a marginally significant negative coefficient after controlling for $B C$.

\section{Table $7 \quad$ Business Cycle Analysis: Univariate Tobit Regressions}

This table provides univariate Tobit regression analyses for IPO volume. $N$ is IPO volume (number of IPOs per year), $H C$ is a dummy variable taking the value of 1 if a particular year is a hot IPO market, 0 otherwise. Money_left is the real aggregate money-left on the table with 2019 numbers. Money_left is computed by multiplying the number of shares offered by the difference between the first trading day close price and the offer price. L.Money_left is the lagged value of money_left. $B C$ is a dummy variable taking the value of 1 if a particular year is in a business-up cycle, 0 otherwise. SEI is a dummy variable taking the value of 1 if the BIST100 index increases in a particular year, 0 otherwise. Primary is the ratio of primary shares to total shares. Primary shares are the additional number of shares issued to increase the number of shares outstanding. IPO_ratio is the percentage of the company's public equity to total equity on the IPO date. CARO is the monthly average of $\operatorname{CAR}(0,0)$ values. T-statistics in parentheses $* * * \mathrm{p}<0.01, * * \mathrm{p}<0.05$, * $\mathrm{p}<0.1$.

\begin{tabular}{|c|c|c|c|c|c|c|}
\hline \multirow[b]{2}{*}{ Variables } & \multicolumn{3}{|c|}{ (1) } & \multicolumn{3}{|c|}{ (2) } \\
\hline & $N$ & Constant & Observations & $H C$ & Constant & Observations \\
\hline Money_left & $\begin{array}{c}0.98 * * \\
(0.45)\end{array}$ & $\begin{array}{c}2.16^{* * *} \\
(0.11)\end{array}$ & 196 & $\begin{array}{l}2.04 * \\
(1.12)\end{array}$ & $\begin{array}{c}1.68 * * * \\
(0.26)\end{array}$ & 183 \\
\hline L. Money_left & $\begin{array}{l}1.82 * * \\
(0.76)\end{array}$ & $\begin{array}{c}1.11 * * * \\
(0.19)\end{array}$ & 195 & $\begin{array}{c}3.63 * * \\
(1.78)\end{array}$ & $\begin{array}{c}0.44 \\
(0.50)\end{array}$ & 183 \\
\hline Proceeds & $\begin{array}{c}0.31 \\
(0.22)\end{array}$ & $\begin{array}{c}2.17 * * * \\
(0.11)\end{array}$ & 196 & $\begin{array}{c}0.72 \\
(0.56)\end{array}$ & $\begin{array}{c}1.68 * * * \\
(0.28)\end{array}$ & 183 \\
\hline L. Proceeds & $\begin{array}{l}-0.37 \\
(0.48)\end{array}$ & $\begin{array}{c}1.32 * * * \\
(0.20)\end{array}$ & 195 & $\begin{array}{c}0.15 \\
(0.92)\end{array}$ & $\begin{array}{c}0.69 \\
(0.51)\end{array}$ & 183 \\
\hline$B C$ & $\begin{array}{c}1.10 * * * \\
(0.39)\end{array}$ & $\begin{array}{l}-0.25 \\
(0.37)\end{array}$ & 312 & $\begin{array}{c}2.04 * * \\
(0.89)\end{array}$ & $\begin{array}{c}-2.26 * * \\
(0.94)\end{array}$ & 312 \\
\hline SEI & $\begin{array}{c}0.04 \\
(0.32)\end{array}$ & $\begin{array}{c}0.62 * * \\
(0.27)\end{array}$ & 312 & $\begin{array}{l}-0.26 \\
(0.66)\end{array}$ & $\begin{array}{l}-0.39 \\
(0.62)\end{array}$ & 312 \\
\hline Primary & $\begin{array}{c}0.00 \\
(0.04)\end{array}$ & $\begin{array}{c}2.26 * * * \\
(0.10)\end{array}$ & 192 & $\begin{array}{l}-1.58^{*} \\
(0.91)\end{array}$ & $\begin{array}{c}3.21 * * * \\
(0.78)\end{array}$ & 179 \\
\hline IPO_Ratio & $\begin{array}{l}-0.00 \\
(0.00)\end{array}$ & $\begin{array}{c}2.31 * * * \\
(0.11)\end{array}$ & 187 & $\begin{array}{l}-0.02 \\
(0.01)\end{array}$ & $\begin{array}{c}2.69^{* * *} \\
(0.48)\end{array}$ & 174 \\
\hline
\end{tabular}

Overall, these results indicate that hot periods do not necessarily coincide with business up-cycles or financial cycles. The real money left on the table is the only significant factor in various specifications. The new shares to total shares ratio is another significant factor in one specification, which might be related to overvaluation periods. Both of these factors are micro factors, indicating that IPO volume is related to the characteristics of particular stocks rather than general economic and financial factors. 
Table 8 Business Cycle Analysis: Multivariate Tobit Regressions

This table provides bivariate Tobit regression analyses for IPO volume. $N$ is IPO volume (number of IPOs per year), $H C$ is a dummy variable taking the value of 1 if a particular year is a hot IPO market, 0 otherwise. $B C$ is a dummy variable taking the value of 1 if a particular year is in a business-up cycle, 0 otherwise. Money_left is the real aggregate money-left on the table with 2019 numbers. Money_left is computed by multiplying the number of shares offered by the difference between the first trading day close price and the offer price. L.Money_left is the lagged value of money_left. Primary is the ratio of primary shares to total shares. The primary shares are the additional number of shares issued to increase the number of shares outstanding. T-statistics in parentheses $* * * \mathrm{p}<0.01, * * \mathrm{p}<0.05, * \mathrm{p}<0.1$.

\begin{tabular}{lcccccccc}
\hline & $(1)$ & $(2)$ & $(3)$ & $(4)$ & $(5)$ & $(6)$ & $(7)$ & $(8)$ \\
Variables & $N$ & $H C$ & $N$ & $H C$ & $N$ & $H C$ & $N$ & $H C$ \\
\hline Money_left & $0.91^{* *}$ & $1.98^{*}$ & $0.87^{*}$ & $1.83^{*}$ & & & & \\
& $(2.00)$ & $(1.76)$ & $(0.46)$ & $(1.09)$ & & & & \\
BC & 0.13 & 0.46 & 0.18 & 0.64 & -0.29 & -0.54 & 0.11 & 0.28 \\
& $(0.42)$ & $(0.62)$ & $(0.31)$ & $(0.72)$ & $(-0.54)$ & $(-0.43)$ & $(0.40)$ & $(0.97)$ \\
L. Money_left & & & & & $1.72 * *$ & $3.72^{* *}$ & 0.24 & 0.84 \\
& & & & & $(2.29)$ & $(2.07)$ & $(0.51)$ & $(1.21)$ \\
Primary & & & -0.48 & $-1.65 *$ & & & -0.39 & -1.66 \\
& & & $(-0.39)$ & $(-0.91)$ & & & $(0.52)$ & $(1.26)$ \\
Constant & $2.10^{* * *}$ & $1.28 *$ & $2.48^{* * *}$ & $2.57 * * *$ & $1.50 * * *$ & 0.90 & $2.83 * * *$ & $3.74 * * *$ \\
& $(7.29)$ & $(1.84)$ & $(0.42)$ & $(0.96)$ & $(3.02)$ & $(0.77)$ & $(0.54)$ & $(1.31)$ \\
Observations & 183 & 183 & 179 & 179 & 183 & 183 & 124 & 124 \\
Pseudo-R2 & 0.01 & 0.01 & 0.01 & 0.02 & 0.00 & 0.01 & 0.00 & 0.01 \\
Chi2 & 4.34 & 3.86 & 5.55 & 7.08 & 5.26 & 4.74 & 0.82 & 2.24 \\
\hline
\end{tabular}

\section{Conclusion}

This paper tests whether market timing theory helps explain the variability in the initial and shortterm aftermarket returns of Turkish IPOs. Findings support the market timing hypothesis: First, there is underpricing of initial returns throughout the analysis period. Second, underpricing is significantly higher in hot issue markets. Third, money left on the table is significantly higher in hot issue markets. Even though univariate analysis shows a positive relation between IPO volume and business up-cycles, this relationship becomes insignificant in multivariate regressions: the real money left on the table takes over the explanatory power of business cycles. The ratio of new shares to total shares takes over the explanatory power of the business cycle when the dependent variable is the hot-and-cold period categorical variable.

Results depending on monthly analysis indicate that hot issue periods do not necessarily coincide with business up-cycles. Hot issue periods are independent of economic and financial cycles. The significant factors related to IPO volume are the money left on the table and the ratio of new shares to total shares, both of which are company characteristics. This outcome implies 
that particular stock characteristics, rather than the general economic and financial environment, shape hot and cold periods.

This paper's findings reveal the advantages and drawbacks of going public in different issue markets. Hot markets may be beneficial for private companies to go public due to overvaluation; however, IPO companies leave significantly higher sums of money on the table during hot issue periods. As a result, hot issue periods are most advantageous for investors.

Private companies and investment banks advising private companies can determine timing strategies, policy makers can advertise IPOs around hot issue markets, and investors can seek higher returns by using the information communicated in this study. There is still large room to test different market timing theories in the Turkish IPO market. Further studies can focus on other theories and investigate why IPO volume has been inert since the beginning of the 2000s. 


\section{References}

Açıkgöz, Ş., and Gökkaya, V. (2017). “Türkiye’de İlk Halka Arz Getirilerinin Değişkenliği,” Ege Akademik Bakış Dergisi, 17(1), 33-58.

Altan, M., and Hotamış, T. N. (2008). “Türkiye’ de Halka İlk Arzı Yapılan Hisse Senetlerinin Kısa Dönem Fiyat Performans Analizi (2000-2006),” KMU IIBF Dergisi, 10(14), 1-36.

Alti, A. (2005). “IPO Market Timing," The Review of Financial Studies, 18(3), 1105-1138.

Baker, M., and Wurgler, J. (2002). "Market Timing and Capital Structure," The Journal of Finance, 57(1), 1-32.

Benveniste, L. M., Ljungqvist, A., Wilhelm Jr., W. J., and Yu, X. (2003). "Evidence of Information Spillovers in the Production of Investment Banking Services," The Journal of Finance, 58(2), 577-608.

Benveniste, L. M., and Spindt, P. A. (1989). "How Investment Bankers Determine the Offer Price and Allocation of New Issues," Journal of Financial Economics, 24, 343-361.

Bildik, R., and Y1lmaz, M. K. (2008). "The Market Performance of Initial Public Offerings in the Istanbul Stock Exchange,” BDDK Bankacılık ve Finansal Piyasalar, 2(2), 49-75.

Binici, M., Hacıhasanoğlu, Y. S., and Kütük, S. (2018). "Finansal Çevrimler ve İş Çevrimlerinin Etkileşimi: Türkiye Örneği,” Bankacılar Dergisi, 105, 63-76.

Boulton, T. J., Smart, S. B., and Zutter, C. J. (2011). "Earnings Quality and International IPO Underpricing," The Accounting Review, 86(2), 483-505.

Breen, Richard. (1996). "Regression Models: Censored, Sample-Selected or Truncated Data," Sage University Papers Series: Quantitative Applications in the Social Sciences, 07-111.

Choe, H., Masulis, R. W., and Nanda, V. (1993). "Common Stock Offerings across the Business Cycle: Theory and Evidence," Journal of Empirical Finance, 2(1), 3-31.

Durukan, M. B. (2002). "The Relationship Between IPO Returns and Factors Influencing IPO Performance: Case of Istanbul Stock Exchange," Managerial Finance, 28(2), 18-38.

Elmas, B., and Amanianganeh, M. (2013). "BIST'de Halka Açılan Şirketlerde Düşük Fiyatlama Anomalisine Etki Edebilen Değişkenlerin Analizi: 1995 - 2010 Dönemi," Afyon Kocatepe Üniversitesi İIBF Dergisi, 15(2), 217-241.

Ercan, M., and Çevikel, S. (2011). "Survey on IPO Underpricing in the Istanbul Stock Exchange," İktisat, İşletme ve Finans, 26(305), 85-117.

Helwege, J., and Liang, N. (2004). "Initial Public Offerings in Hot and Cold Markets," The Journal of Financial and Quantitative Analysis, 39(3), 541-569.

Ibbotson, R. (1975). "Price Performance of Common Stock New Issues," Journal of Financial Economics, 2, 235-272.

Ibbotson, R. G., and Jaffe, J. F. (1975). “'Hot Issue’ Markets,” The Journal of Finance, 30(4), 1027-1042. 
Ibbotson, R. G., Sindelar, J. L., \& Ritter, J. R. (1988). “Initial Public Offerings,” Journal of Applied Corporate Finance, 1(2), 37-45.

Ibbotson, R. G., Sindelar, J. L., and Ritter, J. (1994). "The Market's Problems With the Pricing of Initial Public Offerings," Journal of Applied Corporate Finance, 7(1), 66-74.

Kırkkulak, B. (2009). “Uzun Dönemli Al-ve-Tut Getirileri: İMKB’de Halka Açık Şirketler Üzerine Bir Uygulama,” Ege Akademik Bakış Dergisi, 10(2), 465-486.

Kiymaz, H. (2000). "The Initial and Aftermarket Performance of IPOs in an Emerging Market: Evidence from Istanbul Stock Exchange," Journal of Multinational Financial Management, 10(2), 213-227.

Kıymaz, H. (1997a). “İMKB'de Halka Arz Edilen Hisse Senetlerinin Uzun Dönem Performansları ve bunları Etkileyen Faktörler: İmalat Sektörü 1990-1995 Uygulaması," IMKB Dergisi, $1(3), 47-73$.

Kıymaz, H. (1997b). “IMKB’ de Halka Arz Edilen Mali Sektör Hisse Senetlerinin Performanslarını Etkileyen Faktörlerin İncelenmesi,” IMKB Dergisi, 1(2), 69-90.

Kim, Q., and Weisbach, M. S. (2008). "Motivations for Public Equity Offers: An International Perspective," Journal of Financial Economics, 87(2), 281-307.

Küçükkocaoğlu, G. (2008). "Underpricing in Turkey: A Comparison of the IPO Methods," International Research Journal of Finance and Economics, 13, 162-182.

Loughran, T., and Ritter, J. (2004). "Why Has IPO Underpricing Changed Over Time?," Financial Management, 33(3), 5-37.

Loughran, T., Ritter, J. R., and Rydqvist, K. (1994). "Initial Public Offerings: International Insights," Pacific-Basin Finance Journal, 3(1), 139-140.

Lowry, M., and Schwert, G. W. (2002). "IPO Market Cycles: Bubbles or Sequential Learning?," The Journal of Finance, 57(3), 1171-1200.

Lucas, D. J., and McDonald, R. L. (1990). “Equity Issues and Stock Price Dynamics,” The Journal of Finance, 45(4), 1019-1043.

Maddala G.S. (2018). "Censored Data Models", in The New Palgrave Dictionary of Economics. Palgrave Macmillan, London.

Pástor, L. u., and Veronesi, P. (2005). "Rational IPO Waves," The Journal of Finance, 60(4), 1713-1757.

Plotnicki, M., and Szyszka, A. (2014). "IPO Market Timing: The Evidence of the Disposition Effect among Corporate Managers," Global Finance Journal, 25(1), 48-55.

Rajan, R., and Servaes, H. (1997). "Analyst Following of Initial Public Offerings," The Journal of Finance, 52(2), 507-529. 
Rajan, R., and Servaes, H. (2002). "The Effect of Market Conditions on Initial Public Offerings," Retrieved

from: https://pdfs.semanticscholar.org/20dd/09b6a3da15b176dbfd44edef6d92a74a6914.pdf

Ritter, J. R. (1984). “The 'Hot Issue’ Market of 1980,” The Journal of Business, 57(2), 215-240.

Ritter, J. R. (1991). “The Long-Run Performance of Initial Public Offerings," The Journal of Finance, 46(1), 3-27.

Roosenboom, P. (2012). "Valuing and Pricing of IPOs," Journal of Banking and Finance, 36, $1653-1664$.

Schultz, P. (2003). "Pseudo Market Timing and the Long-Run Underperformance of IPOs," The Journal of Finance, 58(2), 483-517.

Sevim, Ş., and Akkoç, S. (2006). "İlk Halka Arzların Uzun Vadeli Performansları ve Ucuz Fiyat Olgusu: İstanbul Menkul Kıymetler Borsası'nda Sektörel Karşılaştırmalı Bir Uygulama," Dumlupınar Üniversitesi Sosyal Bilimler Dergisi, 16, 107-124.

Subrahmanyam, A., and Titman, S. (1999). "The Going-Public Decision and the Development of Financial Markets," The Journal of Finance, 54(3), 1045-1082.

Tobit, J. (1958). "Estimation Of Relationships for Limited Dependent Variables," Econometrica, 26(1), 24-36.

Turan Kurtaran, A. (2013). “Türkiye'deki İlk Halka Arzların İlk Getirileri İle Uzun Dönem Fiyat Performansları Arasındaki İlişkinin Analizi," International Journal of Economic and Administrative Studies, 6(11), 185-210.

Tütüncü, L. (2020a). “Initial Public Offering Price Support, Valuation, and Returns,” Euroasian Economic Review, 10, 267-282.

Tütüncü, L. (2020b). “Lock-up Provisions and Valuation of Turkish IPOs,” Euroasian Business Review, 10, 587-608.

Tütüncü, L. (2020c). "Valuation and Underpricing of Turkish IPOs," Journal of Business Economics and Management, 21(1), 157-179.

Ünlü, U., and Ersoy, E. (2008). “İlk Halka Arzlarda Düşük Fiyatlama Ve Kisa Dönem Performansın Belirleyicileri: 1995-2008 İMKB Örneği," Dokuz Eylül Üniversitesi İ̈BF Dergisi, 23(2), 243-258.

Y1ldırım, D., and Dursun, A. (2016). "Borsa İstanbul'daki İlk Halka Arzlarda İlk Gün Düşük Fiyat Anomalisi," Atatürk Üniversitesi IIIBF Dergisi, 30(1), 189-202. 